\title{
Bartłomiej Kuczkowski*
}

\section{„Ja z nimi żyć nie mogę..." - oblicza Innej w Powieści bez tytułu Józefa Ignacego Kraszewskiego*}

DOI: http://dx.doi.org/10.12775/LC.2017.039

Streszczenie: Artykul jest interpretacją Powieści bez tytułu (1854) Józefa I. Kraszewskiego jako utworu realizującego schemat kobiecej powieści rozwojowej. Tym samym autor rozwija problematykę dotychczas jedynie zasygnalizowaną przez badaczy. Celem tekstu jest udowodnienie, że Sara Białostocka - główna kobieca postać w utworze - to bohaterka oryginalna, nietuzinkowa: Inna. Jej odrębność wyraża się zarówno na poziomie przynależności kulturowo-religijnej (jest Żydówką), jak i na tle typowych męskich wyobrażeń na temat kobiecości. Życie Sary zostało również skonfrontowane z dyskursywnymi fragmentami powieści, które podejmują temat dorastania człowieka. Tytułowe oblicza Innej to: uczennica Stanisława Szarskiego, czytelniczka „książek zbójeckich”, kapłanka sztuki i zimna, zdystansowana aktorka Smaragdina. Prześledzenie kolejnych wcieleń bohaterki pozwala uwydatnić jej zmagania z otoczeniem oraz z własną tożsamością.

Słowa kluczowe: Józef Ignacy Kraszewski, powieść realistyczna, powieść rozwojowa, kobiety w literaturze, dojrzewanie w literaturze

\footnotetext{
* Doktorant w Zakładzie Tekstologii i Edytorstwa Dzieł Literackich Uniwersytetu Mikołaja Kopernika w Toruniu. Interesuje się m.in. edytorstwem, zwłaszcza tekstów dziewiętnastowiecznych, kreacjami bohaterów literackich w prozie XIX wieku. Przygotowuje dysertację poświęconą pismom filozoficznym Zygmunta Krasińskiego. E-mail: bart.kucz@gmail. com.

** Artykul jest skróconą wersją poświęconego Powieści bez tytułu rozdziału pracy magisterskiej Zapis kobiecego dojrzewania w powieści polskiej XIX wieku, napisanej pod kierunkiem prof. dr hab. Ewy Owczarz. Praca uzyskała wyróżnienie honorowe w Konkursie im. Czesława Zgorzelskiego w 2015 roku.
} 


\title{
"I cannot live with them..." - the faces of the Other in the Novel without a title by Józef Ignacy Kraszewski
}

\begin{abstract}
The article should be perceived as an interpretation of the Novel without a title 1854 by J. I. Kraszewski as a feminine novel of character development. The issue has so far been only signalised by some literary authorities. The text is to prove that Sara Białostocka the main character of the novel is a unique individuality and unlike other female characters. Her distinctiveness can be seen in her cultural background (She's Jewish) as well as in juxtaposition with the typical male perspective on femininity. The life of Sarah was also confronted with the parts of the novel that deal with the maturing of men. The typical faces of the other are: a student of Stanisław Szarski, the reader of ruffinaly novels, the goddess of art as well as the cold and detached Smaragdin actress. Looking at different incarnations of the character enables readers to observe the identity and surrounding struggle that Sarah experiences.
\end{abstract}

Key words: Józef Ignacy Kraszewski, realist novel, novel of character development, women in literature, personal growth in literature

otychczasowe odczytania Powieści bez tytułu (1854) Józefa Ignacego Kraszewskiego dotyczyły przede wszystkim kilku zasadniczych problemów. Po pierwsze, komentowano autobiograficzne wątki utworu i poszukiwano rzeczywistych odpowiedników poszczególnych postaci ${ }^{1}$. Po drugie, omawiano postacie Żydów w powieści, koncentrując się raczej na jej ogólnej wymowie - Sara Białostocka dzięki wyrazistej, złożonej osobowości i skomplikowanemu życiu uczuciowemu miała dawać świadectwo odważnego i demokratycznego podejścia Kraszewskiego do kwestii żydowskiej². Wreszcie, omawiając budowę i treść powieści, badacze często widzieli na pierwszym planie fabułę i próbowali ją rozmaicie określać - jako sensacyjną, awanturniczą, przygodową czy melodramatyczną ${ }^{3}$.

\footnotetext{
1 W. Danek, Józef Ignacy Kraszewski, Warszawa 1962, s. 67 i n. Tego rodzaju lektura zdaje się stać w sprzeczności z zamiarem samego Kraszewskiego, który ostrzegał przed czytaniem powieści w sposób nachalnie biograficzny - na ten temat zob. W. Hamerski, Romantyczna troposfera powieści, Poznań 2010, s. 46-47. Źródło wątku miłosnego Sary Białostockiej i Stanisława Szarskiego widziano w młodzieńczym uczuciu Kraszewskiego do pięknej uczennicy - S. Burkot, Kobieta w powieściach i publicystyce Kraszewskiego, [w: ] Kraszewski. Poeta i światy, red. T. Budrewicz, E. Ihnatowicz i E. Owczarz, Toruń 2012, s. 303.

2 A. Zyga, Problem żydowski w twórczości J. I. Kraszewskiego, „Rocznik Komisji Historycznoliterackiej”, t. 2, Wrocław 1964, s. 167; W. Danek, op. cit., s. 68. Nie oznacza to jednak, że nie dostrzeżono przedtem również odrębności i oryginalności interesującej nas postaci. Józef Bachórz opisuje kreacje kobiet „zdumiewające na tle tradycji polskiej oryginalnością, odległe od stereotypów”, a wśród nich Sarę, która „wyrasta nad pospolitość romansowych heroin inteligencją, odwagą buntu, samowiedzą tragiczną" - Zdziwienie Kraszewskim, [w:] Zdziwienia Kraszewskim, red. M. Zielińska, Wrocław 1990, s. 152. Z kolei Kazimierz Czachowski upatruje oryginalności bohaterki w przenikającym ją niemal na podobieństwo objawienia religijnego żywiole poetyckim. Określa on Sarę jako „naturę egzaltowaną i namiętną, pozbawioną wiary, bo » wiarą jej była poezja sama «, wyjątkową u Kraszewskiego i w ogóle w naszej powieści postać wielkiej miłośnicy” - Między romantyzmem a realizmem, Warszawa 1967, s. 103

3 Wincenty Danek wyodrębniał trzy style językowe powieści - realistyczny, biblijny i sentymentalny właśnie, pojawiający się w scenach erotycznych i wypowiedziach o twórczości pisarskiej - op. cit., s. 69. Jerzy Fiećko przeanalizował melodramatyczny schemat losów Stanisława (opiekuna) i Sary (ofiary) - Kwestia żydowska we wspótczesnych powieściach Kraszewskiego. „Latarnia czarnoksięska”, „Powieść bez tytulu”, „Żyd”, [w:] Europejskość i rodzimość. Horyzonty twórczości Józefa Ignacego Kraszewskiego, red. W. Ratajczak i T. Sobieraj, Poznań 2006, s. 239-240. Jerzy Tynecki sugerowal, by nie skupiać się na wątku miłosnym Stanisława i Sary i z pewną dozą ironii pisał o wątku porwania bohaterki: „Jakkolwiek dramatyzuje te wypadki opinia, należą one do rzędu prowincjonalnych ewenementów, jakie z czasem przechodzą do kroniki obyczajowej, przecho-
} 
Wydaje się, że wskazane nastawienia wobec utworu nie pozwoliły ukazać głównej postaci kobiecej w jej charakterologicznym bogactwie, nie opisano również zbyt obszernie napięć i problemów, jakie wiążą się ze skomplikowanymi stosunkami powieściowej Innej, Sary Białostockiej, z otoczeniem ${ }^{4}$. Ważne sensy dzieła odsłonią się, jeśli uznamy je - ze względu na rozwiązania kompozycyjne i fabularne - za utwór realizujący schemat powieści rozwojowej ${ }^{5}$. Inność dojrzewania Sary należy przy tym postrzegać wielopłaszczyznowo - zarówno na tle przedstawionego w powieści, głównie w wypowiedziach narratorskich i kreacjach postaci tła (Adeli czy Marylki), określonego modelu procesu wchodzenia człowieka w dorosłość, jak i w związku z przynależnością narodowo-etniczną bohaterki oraz jej płcią - ponadprzeciętność Białostockiej ściera się bowiem z męskimi wyobrażeniami na temat kobiecości. Żeby przekonać się o oryginalności tej postaci, przeanalizujemy cztery oblicza, cztery „wcielenia” Żydówki. Kolejno będą to - by przywołać słowa wspominającego bohaterkę poety Stanisława Szarskiego - nieśmiała uczennica, rozmarzona dziewica czytająca Dantego, kapłanka sztuki oraz zimna, zdystansowana bachantka. Dalszy wywód będzie tedy podporządkowany kolejnym etapom dojrzewania bohaterki.

Ukazanie wrastania bohaterów w świat z właściwymi mu pojęciami i stosunkami to ważna cecha powieści rozwojowej ${ }^{6}$. Powieść bez tytułu nie przedstawia jednak formowania się osobowości bohaterki jako procesu, w jego ciągłości i stopniowej, powolnej ewolucji. Specyfika utworu Kraszewskiego polega na pokazaniu przełomowych momentów w biografii postaci, co zbliża dzieło do formy powieści inicjacyjnej ${ }^{7}$. Nie będziemy zatem świadkami gradualnego rozwoju Białostockiej, jej „liniowego” przechodzenia od młodości do dojrzałości, lecz raczej obserwatorami kolejnych wyjść bohaterki na scenę. Tym samym egzystencjalne zmagania Sary z otoczeniem, starcia sposobów myślenia i odczuwania staną się widoczne szczególnie jaskrawo. Zobaczymy też, jaki wpływ na rozwój kobiety wywarly krępujące ją ograniczenia środowiskowe i światopoglądowe.

Jak ukazuje się nam Sara po raz pierwszy? W jej początkowych opisach łatwo dostrzec od razu symptomy inności. Na poziomie najbardziej oczywistym jest to przynależność na-

wywanej w jakichś niedyskretnych wspomnieniach” - Imię rodowe, imię wtasne, czy pseudonim ostaniający. Co przystoi poecie w „Powieści bez tytułu” Kraszewskiego, „Prace Polonistyczne” 1989, ser. XLV, s. 131. Romantyczną niezwykłość przygód, awanturniczość i sensacyjność fabuły akcentował Kazimierz Czachowski - op. cit., s. 103.

4 Problem ten nie dotyczy zresztą tylko Powieści bez tytułu. Na „niedoczytanie” postaci kobiecych w twórczości Kraszewskiego powstałej po 1864 roku zwraca uwagę Mateusz Skucha w inspirującej pracy Eadni chtopcy i szalone. Męskość i kobiecość w późnym pisarstwie Józefa Ignacego Kraszewskiego, Kraków 2014, passim. Również Józef Bachórz odnotowuje, iż „przez wiek cały w naszych badaniach literackich nad Kraszewskim nie doceniano znaczenia tematyki kobiecej w jego utworach”. Ujęcie kobiecości w Powieści bez tytułu uznaje Bachórz za „dalekie od ówczesnych [dziewiętnastowiecznych] naiwnych stereotypów” - J. Bachórz, Lekcje Kraszewskiego, czyli ambaras nadmiaru, [w: ] Kraszewski i wiek XIX. Studia, red. A. Janicka, K. Czajkowski i P. Kuciński, Białystok 2014, s. 48.

5 Sama obserwacja również nie jest nowa. W tekście zamierzamy rozważyć problem dostrzeżony przez Ewę Owczarz Wileńska „Lalka” - „Powieść bez tytutu”, [w: ] eadem, Nieosiagalna całość. Szkice o powieści polskiej XIX wieku, Toruń 2009 , s. 97.

6 Używamy tego określenia, mając jednocześnie świadomość, że kryje się za nim złożona terminologia genologiczna. Badacze mówią o właściwej powieści rozwojowej (Entwicklungsroman), powieści edukacyjnej (Bildungsroman) czy powieści pedagogicznej (Erziehungsroman), a Michał Bachtin rozszerza typologię o powieść wychowawczą w rozmaitych wariantach kompozycyjnych - powieść wędrówek, powieść próby i powieść biograficzna. Zob. T. Sobieraj, Powieści rozwojowe, [w: ] idem, Fabuly i „światopogląd”. Studia z historii polskiej powieści XIX-wiecznej, Poznań 2004; M. Bachtin, Powieść wychowawcza i jej znaczenie w historii realizmu, [w: ] idem, Estetyka twórczości słownej, tłum. D. Ulicka, Warszawa 1986, s. $285-347$.

7 E. Owczarz, Poszukiwanie siebie - poszukiwanie formy. Powieści Kraszewskiego o artyście, [w:] Obrazy kultury polskiej w twórczości Józefa Ignacego Kraszewskiego, red. B. Czwórnóg-Jadczak, Lublin 2004, s. 57; eadem, Dzieje grzechu według Kraszewskiego, czyli poeta i kobiety w „Powieści bez tytulu”, [w:] Album gdańskie: prace ofiarowane profesorowi Józefowi Bachórzowi na siedemdziesiąta piątą rocznicę urodzin i pięćdziesięciolecie pracy nauczycielskiej, red. J. Data i B. Oleksowicz, Gdańsk 2009, s. 420. 
rodowa i religijna, co w ujęciu narratora nosi zresztą znamiona niższości: „[...] młodziuchną Sarę wychowywano starannie pomimo oszczędności, usiłując z niej zrobić panienkę, nie Żydóweczkę" (I 100) ${ }^{8}$. Opozycja ta - znamienna, nie chodzi przecież o Żydówkę, lecz właśnie Żydóweczkę - wskazuje dwa odrębne źródła inności bohaterki: porządek kobiecości i porządek religijny. Oba te aspekty są ważne w kontekście dojrzewania Sary, jak również stanowią o jej atrakcyjności dla męskiego świata w powieści. Spójrzmy, na czym polega ta wyjątkowość:

Rzadko nawet w izraelskiej rodzinie, wśród której nie brak niepospolitych piękności, trafi się coś tak wzniośle i idealnie pięknego, jak Sara - rzekłbyś, wskrzeszona jedna z tych bohaterek Biblii, jedna z tych wdzięcznych dziewic, cór Izraela, które w ognistych wyrazach malują nam księgi święte. W czternastu leciech już się zdawała dojrzałą, tak kibić jej wysmukła, zręczna, doskonale utoczonymi zachwycała kształtami, tak nic nie brakło dziewicy do wyrażenia typu, którego była urzeczywistnieniem szczęśliwym. Płeć jej, nadzwyczajnej śnieżnej białości, przejrzysta, atłasowa, ledwie się nieco rumieniła na twarzy, tak w cieniu i osłonie od powiewu wiatru, od spiekoty słońca, wypielęgnowana była. Profil twarzy azjatycki nadzwyczaj był czystego rysunku i przedstawiał linią idealną nieporównanego wdzięku, oczy miały siłę wejrzenia potężną - osłonione niezmiernej długości rzęsami, nad których arkadą łuk brwi zarysowywał się puszkiem jedwabnym, patrzały z skromnością dziewiczą i śmiałością rozpieszczonego dziecięcia na świat, którego jeszcze tak mało widziały. Niewielkie czoło, gładkie i jasne jak szyba jeziora w dzień pogodny, zdawało się niebo odbijać na sobie, tak było spokojne; uśmiech ust odkrywał bielsze od pereł i piękniejsze od nich ząbki. Ale rzadko gość ten się na nich zjawiał, bo Sara od urodzenia była czegoś smutną, a rodzice wielce się tym trapili, że prawie dzieciństwa i młodości nie znała. Nie bawiły ją zabawki, nie rozrywała igraszka rówieśnic, lubiła dumać, czasem nuciła coś posłyszanego w ulicy, a gdy ją czytać uczyć poczęto, cała się rzuciła do książki (I 101).

Różne zabiegi zastosował Kraszewski, by piękna Sara nie została ukazana schematycznie. Jest ona Inna nie tylko dlatego, że przynależy do „izraelskiej rodziny” - jej wywyższenie polega na włączeniu niebywałej urody do sfery sacrum. Niedościgłego, nietykalnego, ale jednocześnie kojarzącego się z życiem, zmartwychwstaniem, z czystością pierwotnego doświadczenia religijnego. Pierwotność to również egzotyczna dzikość „azjatyckości”, która jednak do głosu tu jeszcze nie dochodzi w pełni. Na razie tłumi ją obraz białej piękności - może niedostępnej kapłanki „malowanej w świętych księgach”, może nie-ludzkiego owocu żywiołu chronionego przez siły samej natury (szyba jeziora, perły, osłona od wiatru) - z pewnością pisarz angażuje tu czytelniczą wyobraźnię ${ }^{9}$, nie wyposażając opisu w cielesność z jej typowym salonowym blaskiem czy przyziemnymi uwikłaniami. Elementy świadczące o bogactwie, przepychu - atłas, puszek jedwabny, perły - przywodzą na myśl blask wspaniałej siedziby. W istocie Sara przypomina nie tyle heroinę romansu, ile budowlę zaprojektowaną przez wybitnego architekta - z „doskonale utoczonymi kształtami”, ,arkadą rzęs" i „łukiem brwi”.

Ten cudownie dostojny gmach nie stoi przecież pusty i martwy - zamieszkuje go dojrzała kobieta. Niech nas nie zwiedzie dorosły wygląd czternastoletniego ciała - wszak ko-

\footnotetext{
8 Wszystkie cytaty z utworu za wydaniem: J. I. Kraszewski, Powieść bez tytułu, t. I-IV, Kraków 1962. W nawiasie podajemy cyfrą rzymską numer tomu, a cyfrą arabską numer stronicy. Wszelkie wyróżnienia w cytatach pochodzą od autora tekstu.

9 O takiej strategii opisu „heroiny romansu” u Kraszewskiego pisze Józef Bachórz - Anatomia heroiny romansu, [w: ] idem, Romantyzm a romanse: studia i szkice o prozie polskiej w pierwszej połowie XIX wieku, Gdańsk 2005, s. 125.
} 
bieta ta „dzieciństwa i młodości nie znała”. W tym kontekście nie chodzi oczywiście o etap życia nierozerwalnie związany z pewnym wiekiem, lecz o specyficzne usytuowanie mentalności wobec egzystencji - inność od typowych nastoletnich dziewcząt, potencjał intelektualny i filozoficzne zamiłowania kojarzone tradycyjnie z męskością. Ta specyficzna dojrzałość współbrzmi z kategorią „dziecięcości” realizującej się w tym momencie jako śmiałość, ale również czystość niedoświadczenia. Wszystko to od razu uderzy Stanisława Szarskiego, który spodziewał się, że przychodzi na pierwszą lekcję do „prostego dziecka wygnanego i skarlałego plemienia" (I 114) - przez tak dosadne określenie Żydów, którego dokonuje bohater szlachecki ${ }^{10}$, Kraszewski osiąga dodatkowy efekt uwypuklenia wyjątkowości Sary na tle zbiorowości.

Metaforyka rzeźbiarsko-architektoniczna, która dyskretnie towarzyszy opisom Białostockiej, nie jest wbrew pozorom niewinna. „Dziewczę było jeszcze wpółdzieciną, uśpioną pieszczotami matki, dusza w niej zaledwie budzić się poczynała do nieznanego życia. [...] Co dzieńt te n posąg nabierał więcej dus zy, a oczy Sary z podbudzoną ciekawością patrzały na księgę i nauczyciela” (I 122). Istotnie, kontakt z nauczycielem pozostaje w tej chwili jedyną znaczącą relacją pozarodzinną dla Żydówki. Nie dziwi to, jeśli wziąć pod uwagę (poza, jak dowiadujemy się w toku narracji, naturalnymi skłonnościami dziewczyny do izolowania się od rówieśnic) także społeczną sytuację kobiety, zwłaszcza w świecie żydowskim, gdzie separacja płci przebiegała bardzo ściśle i nie wierzono w kobiece zdolności do reprezentowania zbiorowości czy pełnienia znaczących funkcji w społeczeństwie ${ }^{11}$.

Szarski nie jest dla Sary li tylko nauczycielem - odgrywa w życiu uczennicy rolę mitycznego Pi g m a li o n a, w rękach którego „posąg nabiera duszy”. W kilku wypowiedziach młodego poety widzimy krzywdzące wyobrażenia na temat rzekomo typowo kobiecego żywiołu cielesności, w którą ducha mógłby tchnąć tylko mężczyzna dzięki swym intelektualnym możliwościom i „wrodzonej” aktywności, wyłącznie jemu przysługującej zdolności do przekształcania świata. Między relacją Szarskiego, stojącego - według własnych, ale i podzielanych wówczas przekonań - wyżej od kobiety w hierarchii społecznej a przekazem narratorskim widać bardzo istotne różnice, które świadczą o wyjątkowości powieściowej Innej, przekraczaniu przez nią nakładanych odgórnie ograniczeń. Nauczyciel Sary tak wspomina swą uczennicę, oglądając ją już na deskach teatru jako Smaragdinę: „nie była to już [...] dzieweczka nieśmiała [!], której wejrzenie tylko mówiło o duszy” (IV 172). Tymczasem według narratora już pierwsza wspólna lekcja wyglądała zupełnie odmiennie, a o nieśmiałości wychowanki nie było w żadnym razie mowy: „Sara słuchała go tak, że każde słowo jego odbijało się w jej oczach pojęte i przyswojone, nie rumieniąc się, nie lękając nawet swej niewiadomości, w prostocie ducha odważnie mu odpowiadając na zapytania” (I 114). Częściowo tę niespójność tłumaczyć można piorunującym wrażeniem, jakie Żydówka wywarła na młodym poecie, należy jednak przede wszystkim zwrócić uwagę na kolejny już aspekt jej inności - uwidaczniający się na poziomie relacji z bliskim otoczeniem swoistym rozmyciem, niepochwytnością czy migotliwością. Widzimy, że idealnie piękne ciało okrywa złożoną osobowość, trudną do jednoznacznego zaklasyfikowania.

10 Głośno wybrzmiewają w tym kontekście słowa Jerzego Fiećki: „dla niego [Szarskiego] samo przyjęcie uczucia dziewczyny wiązało się z aktem ofiary, z ograniczeniem poczucia własnej wyższości”- op. cit., s. 238.

11 W znanej pracy Bożena Umińska syntetycznie porównuje sytuację kobiet w świecie chrześcijańskim i żydowskim Postać z cieniem. Portrety Żydówek w polskiej literaturze od końca XIX wieku do 1939 roku, Warszawa 2001, s. 60-62. 


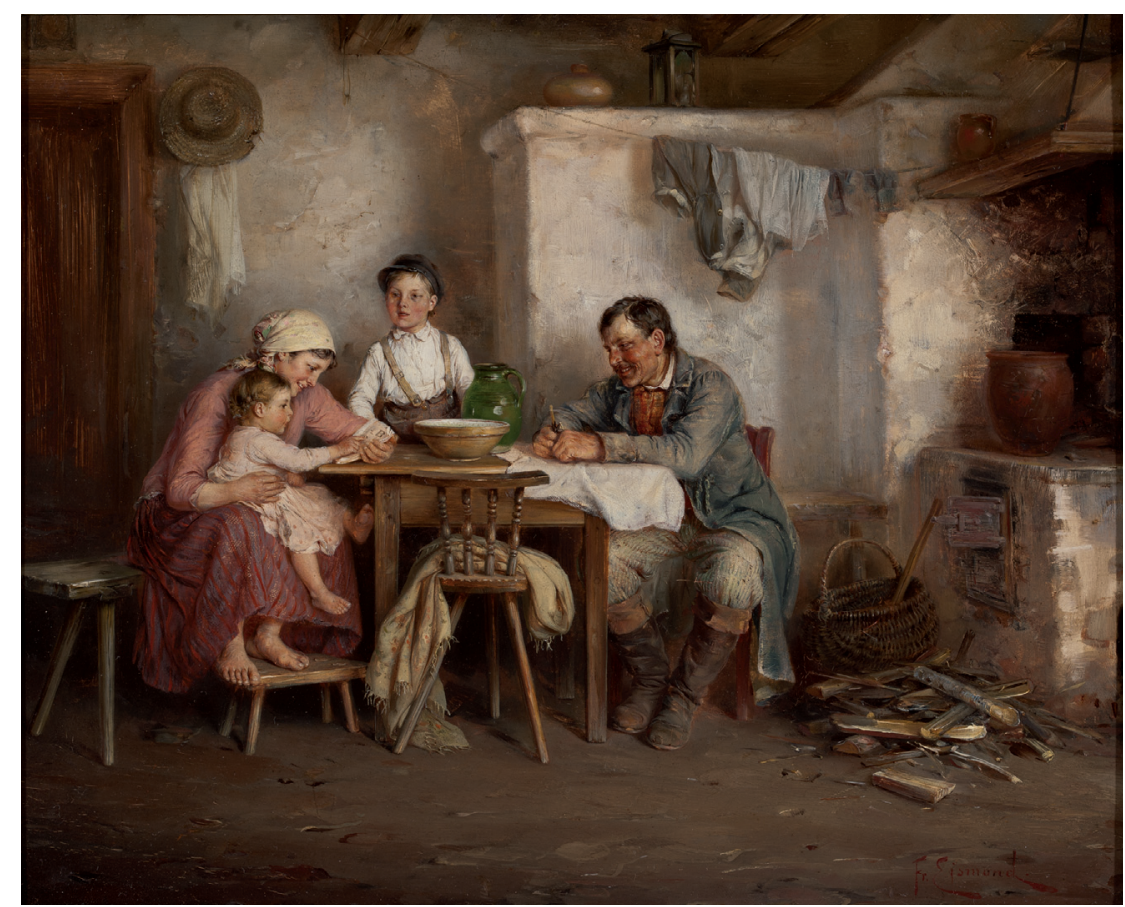

Franciszek Ejsmond, A.B.C. - pierwsze czytanie

Fot. Krzysztof Wilczyński. Ze zbiorów Muzeum Narodowego w Warszawie

Dojrzewanie bohaterki, któremu towarzyszy Szarski-Pigmalion, ma dość osobliwy charakter. „W oczach jego [młodego poety] rozwijał się piękny ten kwiat, który nie potrzebując ani słońca, ani rosy, ani ożywnego powietrza, w sobie niemal samym czerpał siły do wzrostu. Stanisław zdumiewał się postępom i nieraz zadumał nad nimi” (I 136). Pomińmy banalną metaforykę tego fragmentu a zwróćmy uwagę na specyfikę dojrzewania Sary - czerpanie z siebie, nie z otoczenia. Zapewne widzimy tu również ślad osobowości Szarskiego, który nie chce dostrzegać wpływu, jaki wywiera na Żydówkę - być może przestraszył się swej roli rzeźbiarza? Nie ulega jednak wątpliwości, że jest w tym i pierwiastek buntu przeciw wychowaniu „wśród przesądów religii przerosłej wiekami w zabobony, wśród zniewieściających pieszczot, nieświadomości, gnuśnego pokoju, a trafem obdarzonej szczególnymi dary umysłu, któremu nic nie brakło prócz sposobności rozwinienia i uprawy” (I 122). Wyrasta Sara ponad kobiecość - rozumianą w duchu dziewiętnastowiecznego chrześcijaństwa oraz religijnych nakazów judaizmu. Ten ostatni wymiar to przestrzeń strzeżona przez starego Abrama, dla którego czerpanie wiedzy z innych źródeł niż święte księgi to sięganie po diabelski ogień, a nie po wodę (I 139). Inna musi wzrastać w opozycji do takiego świata, musi postępować jej izolacja i odrzucanie niewygodnej, krępującej siły życiowe maski nakładanej kobiecie.

Zasygnalizowany wyżej model dojrzewania jako wyłącznie „czerpania z siebie” jest w praktyce niemożliwy. Zdaje sobie z tego sprawę narrator, gdy w późniejszych częściach utworu snuje refleksje na temat relacji międzyludzkich: „Jak dwa czynniki chemiczne zbliżone do siebie, koniecznie wzajem modyfikować się muszą, tak dusze ludzkie nie mogą pozostać przeciw sobie bezczynne. Jestli co wrażliwszego nad człowieka?” (II 165). Ta nie- 
spójność relacji narratora i Szarskiego podkreśla w powieści rolę, jaką młody poeta odgrywa w życiu Sary. Zapowiada też przełom - narodziny uczucia miłości, które wydobędzie już nie tylko „męskie” ambicje intelektualne bohaterki, ale i jej kobiece cechy. Ciekawe, że narrator mówi w swym wywodzie o istocie słabszej i silniejszej - ale która z postaci jest słabsza? Tą słabszą miałaby być według opowiadacza Sara, na którą Szarski wpływa: „Jest to w naturze człowieka, że ku wyższemu i doskonalszemu się spina, że się w nim musi rozmiłować nareście, i Sara, dla której Stanisław był ideałem, pokochała go najzapamiętalszą młodą namiętnością" (II 166). Choć wyjątkowa i Inna, nie jest Sara przecież zupełnie wyłączona z porządku kobiecości - wyraźnie widać elementy tradycyjnego poglądu na naturę kobiecą: „Wiedziała ona dobrze, że tysiące zapór nieprzebytych, niezwyciężonych dzieli ją od niego; czuła, że Szarski litością chyba wypłacić się jej może, ale nie była panią uczucia i kochać musiała" (II 166). Sara to bohaterka targana sprzecznościami - z jednej strony zdolnościami góruje nad przyporządkowaniami wynikającymi z tradycyjnego porządku płciowego, z drugiej pokochała miłością „kobiecą”. Czy jednak owa bezwolność nie jest przede wszystkim dziełem Szarskiego, który zakochał się w wyrzeźbionym przez siebie posągu?

Spójrzmy, jakie cechy ujawnia bohaterka w dalszej części utworu. Mówimy już w tym momencie o osobie bardziej świadomej, widzimy jej kolejne oblicze, zmianę pod wpływem narodzin miłości. To czas ważnej inicjacji intelektualnej dla bohaterki - „Sara bardzo nieśmiało spytała go potem, czyby jej nie mógł dać książek polskich, czyby nie doradził jej, co ma czytać" (II 169). Jak wiemy, najistotniejszymi lekturami w jej życiu nie staną się może poza poezjami samego Szarskiego - dzieła polskich literatów. Ważne jest za to kolejne pęknięcie, które oddziela Sarę od żydowskiego świata, w jakim się wychowała, a kieruje ją w stronę Inności, metamorfozy ${ }^{12}$. Tej przemiany, którą opłaci cierpieniem, a w końcu chorobą - „biedne dziewczę, śmiejąc się jeszcze usty, wpadło w stan kataleptyczny i skołowaciało w progu z uśmiechem boleści i łzą na powiece” (II 251). Doświadczenie wyobcowanej Innej jest doświadczeniem tylko i wyłącznie kobiecym, niepojętym dla świata męskiego i przez to traktowanym z wyraźnym i nieskrywanym lekceważeniem - dlatego doktor Brant powie: „Zdawało mi się, ale to tylko było coś lekkiego, kobiecego, nerwowego... Rodzice postrzegli, że nadto wyegzaltowali dziewczynę, ale ją teraz za mąż wydają... ślub nastąpi w tych czasach, to będzie dobre antidotum" (II 255). Logiczne, prawdziwie racjonalne wytłumaczenie, które narzuca się z łatwością; należy jednak podkreślić, że choroba to również symptom transgresyjnej metamorfozy - wyraźnie widocznej, a jednocześnie intymnej, kobiecej i niedostępnej poznaniu dla męskiego, szowinistycznego świata powieści.

Opisywany męski punkt widzenia chyba najpełniej ujawnia się w reakcji Stanisława Szarskiego na osobliwości, które zaczynają dziać się w jego izdebce: „wyręczano go w pracy, znajdował, powracając po kilkogodzinnej niebytności w domu, umiecioną podłogę, dzbanek swój wody pełnym, poskładane nieco, niezbyt wyraźnie, ale z pewnym staraniem, ubogie rzeczy swoje” (II 184). Nie może więc dziwić następujący komentarz: „Ten cichy uczynek miłosierdzia w nowym blasku ukazał mu dziewczę, które dotąd widział tylko piękną, ale prawie bezduszną is totą. Pod tą chłodną powierzchownością powolnego i rozpieszczonego dziecięcia biło więc serce dziewicy żywymi ruchy, uczuciem tym droż-

12 Omawiając różne ujęcia tematu żydowskiego w literaturze polskiej, Henryk Markiewicz uznaje poezję za siłę zbliżającą Żydów do polskiego - ale nie tylko polskiego - świata. Vide Asymilacja Żydów jako temat literatury polskiej, [w:] idem, Literatura i historia, Kraków 1994, s. 17. Z kolei Bożena Umińska odnotowuje fakt historyczny ciążenia kobiet żydowskich ku nie-żydowskiemu światu z powodu nieatrakcyjności roli kobiecej w ortodoksyjnym życiu judaizmu - op. cit., s. 78. 
szym, że tajonym i wystarczającym sobie, bo unikającym oczu ludzkich” (II 185-186). Nad przeciętność wynosi Sarę Białostocką działanie miłosierne, realizujące nakazy religijne, choć w perspektywie przytoczonych opisów można by jej pewno przypisać również typową rolę kapłanki domowego ogniska.

Tego zapewne chciałby Szarski. To nadal z jego perspektywy patrzymy na Sarę Białostocką w kolejnych partiach powieści - widzimy idealny obraz, wytwór pragnień bohatera. Zakochany Szarski kontaktuje się bowiem w miłosnej relacji sam ze sobą: „Nic łatwiejszego może nie było, jak spytać o nią, ale Staś tak się obawiał znaleźć swój ideał splugawionym, spospolitowanym, uwiędłym, że wolał nosić go w duszy, jakim mu pozostał" (III 103). W rozterkach i żalu sam zresztą „splugawi” swoją rzeźbę, gdy utożsami żydowskość z przeciętnością oraz stanem rozczarowania życiem: „[... ] bo idealnie była piękną! ale dziś! kiedy z niej zapewne prosta już tylko Żydówka, kiedy dziewiczy urok jej rozwiał się za dotknięciem życia, trzeba być szalonym, ażeby marzyć jeszcze, szalonym i słabym, by kochać...” (III 104-105). To uczucie ma w sobie nie tylko romantyczny bunt przeciw całemu światu, ale przeważa w nim - przynajmniej u Szarskiego - kontemplacja wyobrażeń na temat idealizowanej kobiety nad realnym do niej uczuciem: „Kochał Sarę ... ale ta miłość dziwna była jak marzenie senne, kochał ją i lękał się, i nie znał jej, i czuł się obowiązanym poświęcić jej wszystko, wycierpieć, co go czekało, wypić do dna gorycze życia; ale mógłże się dla niej, dla siebie spodziewać szczęścia?” (III 126).

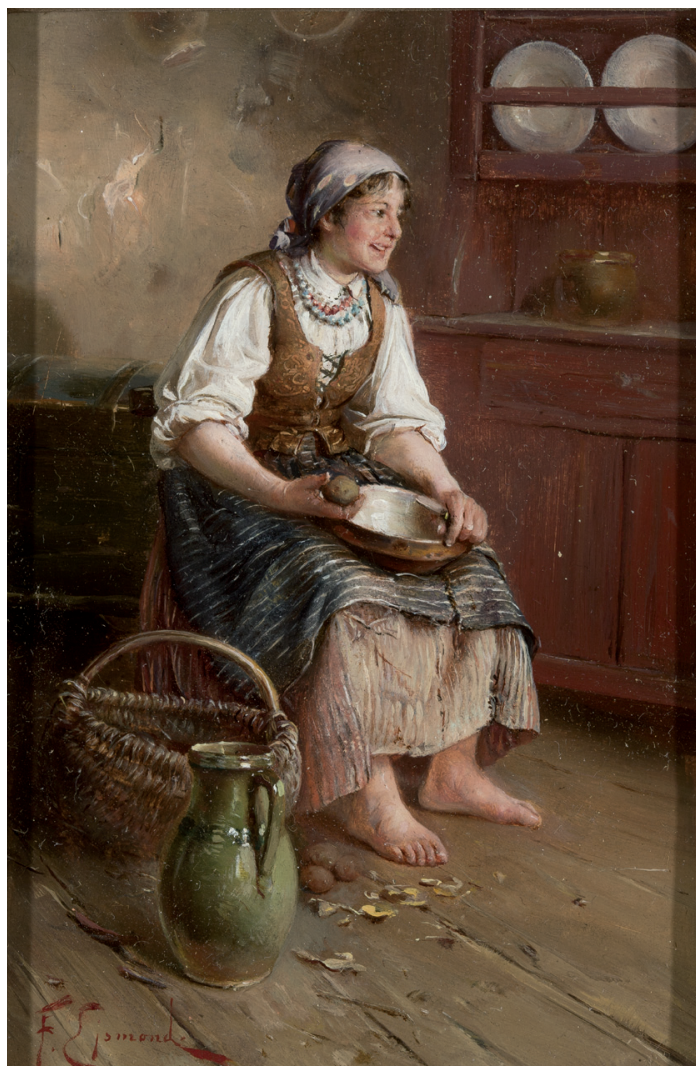

Franciszek Ejsmond, Dziewczyna obierajaca ziemniaki

Fot. Krzysztof Wilczyński. Ze zbiorów Muzeum Narodowego w Warszawie 
Zauważmy, że u podstaw wypowiedzi Stanisława Szarskiego leżą pewne przekonania o istocie procesu dojrzewania człowieka. To zresztą jeden z tematów całej Powieści bez tytułu, pełnej dyskursywnych wzmianek poświęconych młodości i wchodzeniu w dorosłość. $\mathrm{Na}$ samym początku dzieła narrator odnosi się do obrazu zgromadzonych w klasie gimnazjalistów: „W tej skupionej gromadce blisko pięćdziesięciu młodzieży widać było w zarodku wszystką przyszłość każdego; dobitniej nawet i wyraźniej malowały się tu charaktery niż na starszym świecie, gdzie poduczywszy się udawania, ludzie stąpają już ostróżniej i kryją się z grą swoją" (I 11). Z kolei niespełniony nauczyciel, który odkrywa talent Szarskiego, uważa, że „każdy z wesołej młodości przejść później musi w znudzoną uliczkę życia, która w końcu nie wiedzie do niczego, prócz rozbicia o mur głowy” (I 29). Jest to tyleż pesymistyczny, a wręcz fatalistyczny, co uproszczony model przemiany człowieka, który stanowić będzie punkt odniesienia dla odmienności dojrzewania Sary, ale również źródło znaczących motywów, które korespondują z przedstawionymi wydarzeniami i sytuacjami. Przede wszystkim chodzi oczywiście o wielokrotnie powracający w toku powieści motyw gry i aktorstwa.

Przedtem jednak Sara musi stoczyć sama ze sobą najważniejszy bój - o własną tożsamość, a jedna z najważniejszych bitew dotyczy przynależności wyznaniowej i kulturowej. Tak opisuje to sama bohaterka: „Odbierano mi moich poetów, książki moje, pokarm duszy, a zakazywano języka, który stał się myśli tłumaczem, a najgorszym z tyranów był ten, którego zwałam mężem moim ... człowiek ten nie miał litości ... chciał mnie pokonać i nie mógł... i dręczył. Nie mogłam wytrwać, bo wszyscy z nim spiknęli się na mnie, a nikt za nieszczęśliwą nie przemówił...” (III 121). Sytuacja ta ściera się z naturalną ludzką potrzebą przynależności - stąd lęk przed przyjęciem wiary chrześcijańskiej: „Jam nigdy jeszcze nie pomyślała o tym, bo zdało mi się, że jeden jest Bóg dla wszystkich, bom się obawiała tego przekleństwa, które ciąży na nowochrzczeńcach... Oni ani do jednej, ani do drugiej nie przynależą rodziny, obie ich odpychają jak zdrajców” (III 121). Zgodzi się przyjąć nową wiarę po to, by zbliżyć się do ukochanego. Jednocześnie przed Szarskim wyrazi swą tożsamość inaczej: „obcą jestem, Żydówką! zawsze Żydówką! zwalaną żoną cudzą! Tak! tak ...” (III 122). W rozmowie z Dawidem chwilę później deklaruje z kolei: „będę chrześcijanką! jestem chrześcijanką! Tyś mi był ojcem zawsze, matka matką, alem...” (III 124). To nie tylko konflikt wynikający z ewolucji światopoglądowych w rodzinie Białostockich i przynależności pokoleniowej Sary do pierwszej generacji żydowskiego oświecenia ${ }^{13}$, ale następny ważny w jej życiu moment przejścia. Kolejny wymiar inności związanej z wiarą i religią Sary dobrze oddaje powszechnie cytowany przez badaczy fragment: „Wiarą jej była poezja sama ... poezja we wszystkich swych postaciach i wszelkiej swej szacie - biblijna, odwieczna, pierwotna i nowa, od Mojżesza do Heinego! Rozumiała zarówno i czciła na jednym ołtarzu Goethego z pieśniotwórcą Kantyku, króla psalmistę i Danta” (III 145).

Wewnętrzne, tożsamościowe dramaty Sary wynikają właśnie z Inności, z wrażliwości i widzenia więcej, głębiej niż inni ludzie:

$\mathrm{W}$ istocie wyższą nad pospolite Bóg ją obdarzył duszą, która, że nikt ją nie kształcił, że się rozwijała sama, swobodnie, dziko, strzelisto, dziwiła niespodzianymi barwami, w jakich przedstawiała się oku. Dla niej nic nie było pospolitym i śmiesznym, bo w każdej rzeczy i wypadku widziała stronę jego smutną, poetyczną, poważną i wielką, nigdy nie schodząc na ziemię, nigdy

13 A. Zyga, op. cit., s. 167. 
się nie dotykając kału. Potrzeba było poety, by za nią zdążył w jej zachwytach nieustannych, w wędrówkach szalonych po świecie ducha. Sama nieznajomość jego czyniła ją zuchwałą do ostateczności; rzucała się na przedmioty uderzające z tą śmiałością młodości, która niczego zlęknąć się, nic poszanować nie umie. W uwielbieniu, we wstręcie nie znała granic i szła wprost do egzaltacji! Ale na dnie jej duszy brakło najpiękniejszej perły, którą się wieńczą skronie... wiary - tlało w niej przywiązanie patriotyczne do starej Mojżeszowej praojców religii, ale było raczej poetycznym porywem niż przekonaniem głębokim... księgi chrześcijan, które czytała, wskazywały jej, co ustarzało w wierze przez współwyznawców jej przechowanej, i czuła, że ślepi umyślnie na nowe światło, widzieć go nie chcieli. Ale między jedną a drugą wiarą pozostała na rozdrożu, a Bóg nie zesłał jej tego daru, tej łaski, tego uczucia, co oświeca nagle, niepojętym sposobem, a którego ani pracą, ani wolą otrzymać niepodobna (III 144-145).

Odrębność Sary widać na przykład, gdy zestawimy ją z Adelą, którą Stanisław obdarzył pierwszym młodzieńczym uczuciem. Poeta spotyka ją po latach, a jego uwagę zwraca głos kobiety, „w którym już ani kropli uczucia, ani odbicia wewnętrznego duszy śpiewu, ani drgania serca nie było: zimny, równy, perłowy, miły uchu, ale przerywany śmiechem sztucznym, wyuczonym i sam wystudiowany jak śpiew kanarka” (III 27). Jednocześnie w ten sposób Kraszewski zapowiada przyszłe wydarzenia w życiu Sary Białostockiej. Adela wypowiada do byłego adoratora symptomatyczne słowa: „nie trzeba być zbyt długo dzieckiem, choćby się kto urodził poetą, bo nic śmieszniejszego nad przedłużone dzieciństwo..." (III 66). Tymczasem dzieciństwo głównych bohaterów należy już do przeszłości. „I dobrze Fredro powiedzial, że kto swe życie bluszczowi temu [sercu kobiety] powierzył, upadnie w przepaść, bo go bluszcz nie strzyma” (III 57). Sara przywdzieje niebawem maskę, której nie wyśniłby chyba ani żaden z wielkich komediopisarzy, ani nawet tragików...

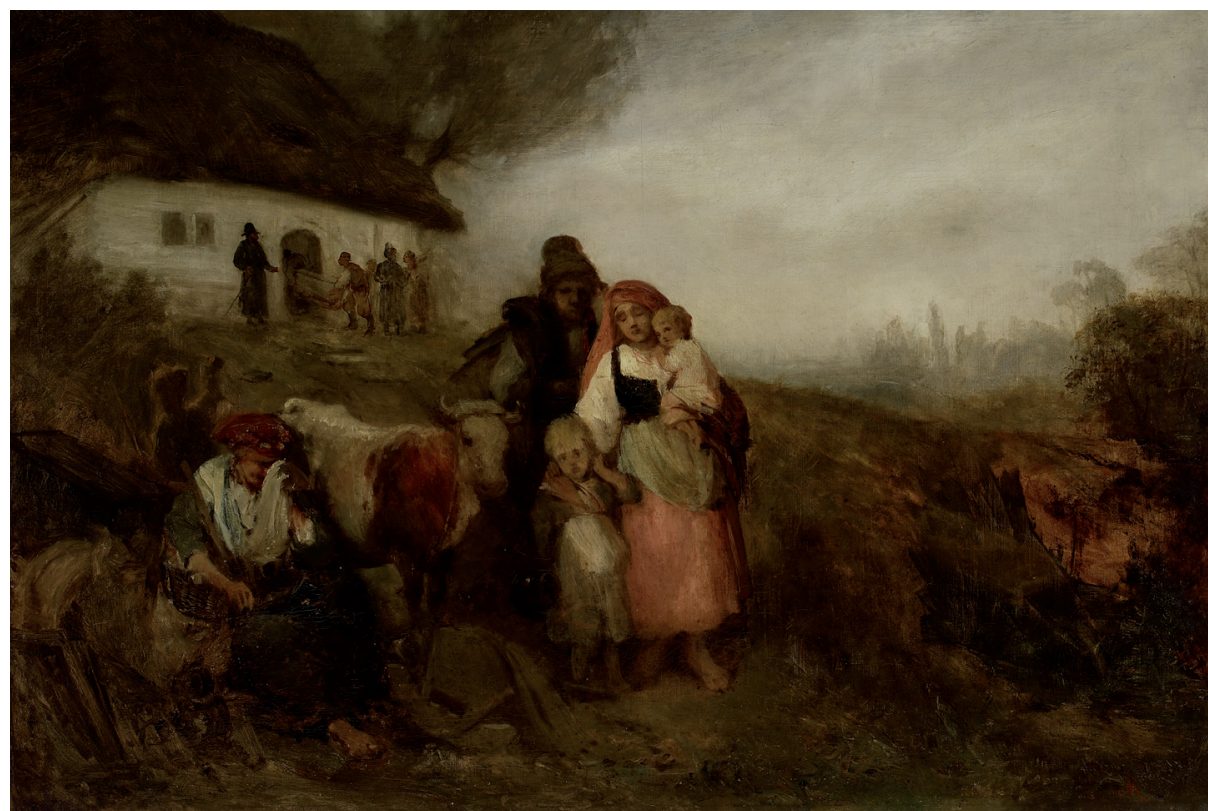

Aleksander Kotsis, Bez dachu, wersja I

Fot. Piotr Ligier. Ze zbiorów Muzeum Narodowego w Warszawie 
Powróci pod imieniem Smaragdiny, aktorki trupy teatralnej, której występ ogląda Szarski w towarzystwie profesora Hipolita. Znamienne, że Sara związała się z teatrem $\mathrm{n}$ i em i e ck i m. Zauważmy, że kamienica Białostockich znajdowała się w Wilnie również przy ulicy Niemieckiej. W ten sposób odbiorca utworu Kraszewskiego-realisty może dodatkowo skojarzyć Sarę i środowisko żydowskie ze sferą obcości, inności - z realistyczną przestrzenią Wilna, ale też z orbis exterior ${ }^{14}$. Szarski obserwuje występ Sary w roli „skromnej a poetycznej dziewicy", zapewne podobnej do dawnej uczennicy. Sam Stanisław widzi jednak Sarę, a nie Smaragdinę: „nie była to już ani owa dzieweczka nieśmiała, której wejrzenie tylko mówiło o duszy, ani rozmarzona dziewica, co ukochała Danta i żyła w poezji; była to istota nowa, może od obu tamtych piękniejsza, ale do żadnej z nich niepodobna” (IV 172). Młodość jako domena ducha szalonego, wyrywającego się, gwałtownego ustąpiła miejsca zimnemu panowaniu nad sobą, rozkazom wydawanym oczom, ustom, całemu ciału. W narratorskiej relacji z teatru trudno czasem oddzielić Sarę i Smaragdinę, co podkreśla dramatyczną wymowę całości i cenę, jaką Sara musiała zapłacić za swoją miłość: „Rola jej była smutna, łzawa, patetyczna, grała ją mistrzowsko, zwłaszcza w tych ustępach, w których Schiller tak umie rzucać się na świat i przeciwko światu z ironią zbolałej duszy" (IV 172) ${ }^{15}$. Wprawdzie Szarski zauważa, że „nic nie straciła z wdzięku dziewictwa i młodości”, ale obserwacja ta odnosi się tylko do wyraźnie obecnego w opisach wymiaru cielesnego kobiety.

Protagonista zastanawia się, „skąd w tej duszy znaleźć się mogły i zabrzmieć nowe struny, na których tak mistrzowsko grała? Skąd taka znajomość natury ludzkiej, jej uczuć i odcieni, to wcielenie się i zjednoczenie z utworem poety?” (IV 173). To przede wszystkim wiedza przynależna dojrzałości czy raczej stanowi nie-młodości. Osiągnęła ją SaraSmaragdina w bólach, okupiła cierpieniami, poniosła ogromne koszty. Opowiada swoją historię - porwanie na skutek spisku rodzin Szarskich i Białostockich, rozkochanie się w Schillerze i decyzja o rozpoczęciu kariery aktorskiej. Wyznaje: „Ale w tej pogoni za sztuką... wszystko... wszystko pogubiłam po drodze! Umiem malować uczucie, ale czuć nie umiem jak dawniej...” (IV 177). W jej gestach, przemowach, sposobie bycia znać tę maskę, którą włożyła, by poradzić sobie z niespełnieniem miłości, z tragedią rozdzielenia z ukochanym. Będzie nawet mówiła po niemiecku, a więc w języku obcym, który symbolicznie rozdziela parę. Sara określana jest teraz jako aktorka, królowa czy heroina. Dusza jej już na zawsze pozostanie uśpiona, ma nie być niczyją - powracamy więc do problemu tożsamości i przynależności. Dostrzegamy również, że Smaragdina staje się za młodu kobietą starą, co możemy interpretować przez pryzmat kobiecego odpowiednika toposu puer senilis (puer senex $)^{16}$. Zauważmy przy okazji, iż w Powieści bez tytułu także Stanisław Szarski staje się puer senex, właśnie po opisywanym przez nas spotkaniu z aktorką: "Jakoż wyzdrowiał wreszcie Szarski, ale ta ostatnia próba go dobiła, wstawszy z łóżka, podniósł się z niego starcem - na pościeli zostawując ostanie tchnienie młodości. Świat wydawał mu się już inaczej, horyzont chmurny, nigdzie przyszłości, podpory, nigdzie na jutro poręki” (IV 180).

\footnotetext{
14 Na temat rozróżnienia na przestrzeń „swoją” i „obcą” pisze Ludwik Stomma - Izolacja świadomościowa, [w:] idem, Antropologia kultury wsi polskiej XIX wieku oraz wybrane eseje, Łódź 2002, s. 163-164.

15 Jak analizuje Ewa Owczarz, „Schiller patronuje w powieści temu, co tragiczne, buntownicze, romantyczne; Goethe temu, co umiarkowane, wyważone, zorientowane społecznie, a nie indywidualistyczne” - zob. Wileńska „Lalka”..., s. 114.

16 Zob. E. R. Curtius, Literatura europejska i tacińskie średniowiecze, tłum. i oprac. A. Borowski, Kraków 1997, s. 107-114. Przykładami realizacji toposu starej kobiety i dziewczyny są stara i pełna żywotności filozofia u Boecjusza czy postać kościoła-starej kobiety we wczesnochrześcijańskiej literaturze wizyjnej. Często toposowi temu towarzyszy zjawisko odmłodzenia, które można interpretować jako pragnienie odrodzenia osobowości.
} 
Sara wraz ze swoim teatrem ponownie przyjedzie do Wilna. Oglądamy ją po kolejnym przeobrażeniu, jeszcze bardziej powściągliwą w okazywaniu uczuć - niemal nie reaguje na przybycie Szarskiego. „Wdzięcznie spadała jej bladolila sukienka z nóg wyciągniętych na sofie, na których rozwieszona była jak draperia greckiego posągu, ręka jedna półkolem zginała się nad głową spoczywającą na poduszce karmazynowej, odsłaniając śliczną szyję i część popiersia cudnych kształtów i śnieżnej białości” (IV 273). Powraca tu porównanie Sary do dzieła architektonicznego, Smaragdina jest niemal posągiem - tak zimna, tak brak w niej wcześniejszej żywości duszy. Towarzyszy jej książę Rubiaków, człowiek cyniczny i gardzący taką miłością, jaka stała się doświadczeniem Szarskiego. Dawna młodzieńcza śmiałość i świadomość własnej wartości Sary zostaje teraz zupełnie stłamszona w relacji z księciem, który zimnego, okrutnego i obojętnego nie gra - w przeciwieństwie do Smaragdiny - lecz istotnie takim jest. Sam się do tego przyznaje: „nie głupim stawić życie na serce kobiety!, nie! nie! Wiesz dobrze, że moja miłość inaczej wygląda; miłość to próżniacza, książęca, kapryśna, dziś milion płacąca za to, co jutro za grosz ma sprzedać... Gdybym miał w sobie to wielkie i piękne uczucie, którym ten człowiek [Szarski] goreje, użyłbym go na co innego" (IV 275). Sara w obecności Szarskiego korzy się przed Rubiakowem, błaga go o uznanie i adorację, co brutalnie obnaża istotę tego związku, a przede wszystkim smutny los bohaterki, skazanej na wieczne aktorstwo. Tak niepospolita i wyjątkowa niegdyś kobieta teraz patrzy tylko - niemal jak Adelka - „wzrokiem wyuczonej zalotnicy”, a swego ukochanego, Szarskiego, nazywa dzieckiem. Bezlitośnie wskazuje na jego ubóstwo, co ma utwierdzić go w przekonaniu, że ich miłość była niemożliwa do spełnienia - sama mówi o sobie: „Kapłanka poezji i piękności nie może znieść nędzy i niedostatku ... ja potrzebuję zbytku, pieniędzy, złota ... i swobody, która się za nie kupuje. [...] ja muszę żyć w tych złotych ramach, bez których nie pojmuję życia ...” (IV 276). Czy jednak nie jest zupełnie odwrotnie? Sara zdołała pojąć życie na tyle, by zrozumieć, czym są nieprzekraczalne ramy ograniczeń kulturowych, wśród których przyszło jej dorastać. Kupna swoboda byłaby zatem rozpaczliwą ucieczką ku kalekiej, pozornej wolności, a w istocie ku zniewoleniu „złotych ram" bogactwa materialnego, za które bohaterka płaci sobą - własną wyjątkowością i nieprzeciętnością.

Czyżby więc dzieje Sary Białostockiej miały jednak potwierdzać wyrażone w Powieści bez tytułu prawdy na temat spustoszeń, jakie w młodzieńczych duszach ma czynić dorastanie? Nie zapominajmy, że Smaragdina w czasie spotkania z Szarskim wciąż nie zeszła ze sceny - gra teraz dojrzałą kobietę, dla której przeszłość i uczucie do Szarskiego były tylko „szczęściem dziewczęcia” (IV 278). W rolę wciela się tak przed kochającym ją literatem, jak przed widzami w kolejnej sztuce teatralnej. Zwraca uwagę rola, jaką przypisano jej w scenariuszu. Już nie jest „poetyczną dziewicą”, lecz „jedną z tych pospolitych teatralnych kochanek $[\ldots]$ typ ten wystereotypowany we wszystkich sztukach, tak jest oklepany, powszedni, tak starty, że jak z starego łachmana nic już zeń zrobić nie można” (IV 283). A jednak Sara zagrała wyśmienicie - $\mathrm{z}$ autentycznym ogniem uczuć, namiętnością, oryginalnością Szarski uważa, że ukochana w tej roli „była sobą - taką, jaką w głębi jest jej dusza!” (IV 285). W sposób paradoksalny przenikają się tu sfery prawdy i fikcji literackiej, autentycznego życia i przekonującego aktorstwa. Spomiędzy nich widoczny jest jednak bardzo wyraźnie dramat Sary. Oddajmy głos narratorowi: „Czy Smaragdina znów grała rolę jaką, czy była tylko sobą i najszczerszym swej myśli wyrazem, nie wiem - ale coś w jej oku przelatywało jak uczucie, coś w ustach jakby żal drgało. Zdawało się, że odpychała go umyślnie, jak gdyby 
czuła, że uścisk jej skalany jest i zatruty, że się nie godzi zapłacić nim za szczerą, za poczciwą miłość poety" (IV 286).

Zwróćmy jeszcze uwagę na epilog powieści. Życie Szarskiego dobiega końca, pod jego oknami Sara płacze z rozpaczy. „Na piasku nieraz uklękła Sara, pożerając oczyma ofiarę swoją, do której zbliżyć się nawet, by przebaczenie wymodlić - nie mogła” (IV 298). Poeta z pewnością przebaczyłby, zresztą przeczuwa obecność ukochanej, ma widzenie postaci w bieli. Żydówka o Szarskim przecież myśli stale i nie zapomni go już nigdy: „W lat dwa, w lat dziesięć jeszcze taż sama dłoń, w ten sam dzień przychodziła z danią pogrobową na mogiłę już dzikimi chwastami pokrytą ... i nikt więcej! i nikt więcej!” (IV 301). Z pewnością jako strażniczka pamięci po utalentowanym, lecz nie zawsze docenianym poecie, odpokutuje swe winy...

Sara nie jest katem Stanisława, jak sama uważa, lecz przede wszystkim ofiarą. Ofiarą własnej wyjątkowości, nadzwyczajności, Inności. Płaci za nią wyalienowaniem, niemożnością osiągnięcia równowagi, wiecznym rozdarciem, trudnością w zbudowaniu własnej tożsamości. Płaci również tragiczną, niespełnioną miłością - podlega tej „sile fatalnej”, „sile ciemnej”, która tkwi w naturze ${ }^{17}$. Płaci najwyższą cenę - utraty godności, samoponiżenia, „zaprzedania” swojej duszy. Wciąż musi wkładać kolejne maski, wciąż musi grać, by mieć poczucie przynależności, być częścią jakiegoś świata - choćby tak bezwzględnego, cynicznego i okrutnego jak świat księcia Rubiakowa. Narrator przedstawia nam w jednej z końcowych scen powieści myśli Szarskiego: „któż pojmie serce? kto zrozumie taką niewiastę, jak ona?...” (IV 295). Uważny czytelnik Powieści bez tytułu - widzianej nie tylko jako jedna część cyklu Kraszewskiego powieści o artyście, ale również u t w ó r o a r t y s t c e - może Sarę zrozumieć, gdy tylko zobaczy więcej, niż widział Szarski, ograniczony przez własne i podzielane $\mathrm{w}$ przedstawionym $\mathrm{w}$ powieści środowisku przekonania na temat kobiecości. Ale czy możemy bohaterkę zrozumieć w pełni? Bądźmy ostrożni i nie popadajmy w pychę. To przecież Inna.

\section{Bibliografia}

Bachórz Józef, Anatomia heroiny romansu, [w:] idem, Romantyzm a romanse. Studia i szkice o prozie polskiej w pierwszej połowie XIX wieku, Gdańsk: Wydawnictwo Uniwersytetu Gdańskiego, 2005.

—, Lekcje Kraszewskiego, czyli ambaras nadmiaru, [w:] Kraszewski i wiek XIX. Studia, idea i uklad tomu Jarosław Ławski, red. Anna Janicka, Krzysztof Czajkowski i Paweł Kuciński, Białystok: Książnica Podlaska im. Łukasza Górnickiego, 2014.

—, Zdziwienie Kraszewskim, [w:] Zdziwienia Kraszewskim, red. Marta Zielińska, Wrocław: Zakład Narodowy im. Ossolińskich, 1990.

Bachtin Michał, Powieść wychowawcza i jej znaczenie w historii realizmu, [w:] idem, Estetyka twórczości słownej, tłum. Danuta Ulicka, oprac. i wstęp Eugeniusz Czaplejewicz, Warszawa: Państwowy Instytut Wydawniczy, 1986.

\footnotetext{
17 Zob. S. Burkot, Kobieta, emancypacja i „sprawy fatalne” w twórczości Kraszewskiego, [w:] Kraszewski-pisarz wspótczesny, red. E. Ihnatowicz, Warszawa 1996, s. 147-156.
} 
Burkot Stanisław, Kobieta, emancypacja i „sprawy fatalne” w twórczości Kraszewskiego, [w:] Kraszewski - pisarz wspótczesny, red. Ewa Ihnatowicz, Warszawa: „Elipsa”, 1996.

—, Kobieta w powieściach i publicystyce Kraszewskiego, [w:] Kraszewski. Poeta i światy, red. Tadeusz Budrewicz, Ewa Ihnatowicz i Ewa Owczarz, Toruń: Wydawnictwo Naukowe Uniwersytetu Mikołaja Kopernika, 2012.

Curtius Ernst Robert, Literatura europejska i łacińskie średniowiecze, przeł. i oprac. Andrzej Borowski, Kraków: Universitas, 1997.

Czachowski Kazimierz, Między romantyzmem a realizmem, oprac. Adam Czachowski, wstęp Jarosław Maciejewski, Warszawa: Państwowy Instytut Wydawniczy, 1967.

Danek Wincenty, Józef Ignacy Kraszewski, Warszawa: Państwowe Zakłady Wydawnictw Szkolnych, 1962.

Fiećko Jerzy, Kwestia żydowska we wspótczesnych powieściach Kraszewskiego. „Latarnia czarnoksięska”, „Powieść bez tytułu”, „Żyd”, [w:] Europejskosśc i rodzimość. Horyzonty twórczości Józefa Ignacego Kraszewskiego, red. Wiesław Ratajczak i Tomasz Sobieraj, Poznań: Wydawnictwo Poznańskiego Towarzystwa Przyjaciół Nauk, 2006.

Hamerski Wojciech, Romantyczna troposfera powieści. Interpretacje prozy Kraszewskiego, Sztyrmera i Korzeniowskiego, Poznań: Wydawnictwo Poznańskie, 2010.

Kraszewski Józef Ignacy, Powieść bez tytułu, t. I-IV, Kraków: Wydawnictwo Literackie, 1962.

Markiewicz Henryk, Asymilacja Żydów jako temat literatury polskiej, [w: ] idem, Literatura i historia, Kraków: Universitas, 1994.

Owczarz Ewa, Dzieje grzechu wedlug Kraszewskiego, czyli poeta i kobiety w „Powieści bez tytulu”, [w: ] Album gdańskie: prace ofiarowane profesorowi Józefowi Bachórzowi na siedemdziesiąta piata rocznicę urodzin i pięćdziesięciolecie pracy nauczycielskiej, red.Jan Data i Bolesław Oleksowicz, Gdańsk: Wydawnictwo Uniwersytetu Gdańskiego, 2009.

—, Poszukiwanie siebie - poszukiwanie formy. Powieści Kraszewskiego o artyście, [w:] eadem, Nieosiagalna całość. Szkice o powieści polskiej XIX wieku, Toruń: Wydawnictwo Naukowe Uniwersytetu Mikołaja Kopernika, 2009.

—, Wileńska „Lalka” - „Powieść bez tytułu”, [w:] eadem, Nieosiagalna całość. Szkice o powieści polskiej XIX wieku, Toruń: Wydawnictwo Naukowe Uniwersytetu Mikołaja Kopernika, 2009.

Skucha Mateusz, Ładni chłopcy i szalone. Męskość i kobiecość w późnym pisarstwie Józefa Ignacego Kraszewskiego, Kraków: Collegium Columbinum, 2014.

Sobieraj Tomasz, Powieści rozwojowe, [w:] Fabuly i „światopogląd”. Studia z historii polskiej powieści XIX-wiecznej, Poznań: Wydawnictwo Naukowe Uniwersytetu im. Adama Mickiewicza, 2004.

Stomma Ludwik, Antropologia kultury wsi polskiej XIX wieku oraz wybrane eseje, wyd. 2, Łódź: Piotr Dopierała, 2002.

Tynecki Jerzy, Imię rodowe, imię własne, czy pseudonim osłaniający. Co przystoi poecie w „Powieści bez tytułu” Kraszewskiego, „Prace Polonistyczne” 1989, ser. XLV, Łódź, Łódzkie Towarzystwo Naukowe.

Umińska Bożena, Postać z cieniem. Portrety Żydówek w polskiej literaturze od końca XIX wieku do 1939 roku, Warszawa: „Sic!”, 2001.

Zyga Aleksander, Problem żydowski w twórczości J. I. Kraszewskiego, „Rocznik Komisji Historycznoliterackiej”, t. 2, Wrocław, Zakład Narodowy im. Ossolińskich 1964. 